\title{
PENGAPSAHAN: TRANSLATION MODELS, LOCAL LANGUAGE PRESERVATION, AND LANGUAGE ACCULTURATION PROCESSES IN KIAI BOOKS OF COASTAL JAVA
}

\author{
Muhamad Jaeni \\ Institut Agama Islam Negeri (IAIN) Pekalongan, Indonesia \\ Jl. Pablawan, Rowolaku Kajen Kabupaten Pekalongan, Jawa Tengah, 51161, Indonesia \\ CorrespondingE-mail:m.jaeni@iainpekalongan.ac.id
}

\begin{abstract}
Pengapsahan model is a translation model that has long been used by Kiai in several traditional pesantren (Islamic boarding schools) on coastal Java. During this time, the conjugation model is only understood as a tool for analyzing text structures, whereas far more than that, there is a variety of Javanese typically used in pesantren having a social role so that the variety of Javanese is still preserved by pesantren communities. This paper examines the model of analyzing the pesantren books. The study will also look at the formulation of Kitabi Javanese language and the reasons why the variety of Javanese of the pesantren that continues to be preserved and maintained by the pesantren community, as well as how the process of conjugation has become a part of the process of acculturation in Javanese and Arabic in the texts of religious books. The results of this study, First, the conjugation model is a special model for Arabic texts created by Islamic boarding school scholars with various analytical tools in it; Second, the variety of languages used in the conjugation of the book is a variety of Javanese of coastal dialects and it has become a corpus of its language which is called Jawa Kitabi (Kitabi Javanese); Third, the process of acculturation of Arabic-Javanese in the tradition of conjugation is characterized by the emergence of the pegon script, the emergence of Javanese translation books with the Arabic structure of fusha, the existence of mixed code phenomena in the writing and translating pesantren books, both mixed codes of Javanese-Arabic, Javanese-Indonesian and mixed codes of Javanese Krama-Ngoko.
\end{abstract}

Keywords: $\quad$ Pengapsahan, language acculturation, Kiai books, local language preservation

\section{Introduction}

The pengapsahan model is a translation model that has long been used by scholars in several traditional Islamic boarding schools. In the pengapsaban model, there are at least three points of view that need to be understood, namely as the process of teaching reading Arabic texts, grammar learning activities, and translation 
activities. ${ }^{1}$ The three elements of conjugation appear in the translation books of coastal Kiai (Islamic Scholar). At the linguistic level, there are several activities in the text analysis of the input model, namely; giving grammatical signs of the structure and meaning of the word; giving the correct harakat in each word according to the rules of language (nahwu, sharaf, and balaghah); discussing all the grammatical signs into the Javanese language; and giving partial meanings for each unit of language to the smallest unit of language. While in the translation context, an important element that needs to be studied is the variety of Javanese used in the conjugation of books. This is important to pay attention to because, in broad outline, the variety of Javanese conjugated in the book is not a colloquial speech as commonly used by Javanese people in general.

The elements of local language in the conjugation of the book are the basis for the formation of a variety of Javanese typical of pesantren which are often referred to as Kitabi Javanese. In formulating the variety of Kitabi Javanese it is necessary to look at the used characters. In pesantren Javanese, the variety of characters is often referred to as Pegon Arabic script. ${ }^{2}$ Mahfudz mentions that the word "Pegon" comes from the Javanese "Pego" which means it is not common in pronunciation (ora lumrah anggone ngucapake) or "unusual in pronounciation." It is called as "Pego" because the letters deviate from the rules of Arabic script and also the rules of Javanese writing, such as the

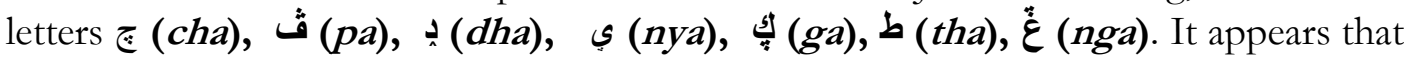
the letters are from the Arabic script, but the language is Javanese, Sundanese, Madurese or other local languages that exist in the archipelago. ${ }^{3}$ To see the difference in the form of fusha Arabic with pegon Arabic, it is usually based on differences in both systems of sound (phonetics). However, the tradition of Pegon writing which in fact as a legacy of Islamic boarding school scholars, is now slowly being abandoned.

Besides the literary form, the important element in the conjugation of the book is the use of various dialects. In sociolinguistics, the study of language use (characters and dialects) is an interesting study for researchers from Indonesia and foreign countries. ${ }^{4}$ Some of these studies examine how the language was chosen, used,

1 Irhamni, "Kearifan Lokal Pendidikan Pesantren Tradisional di Jawa: Kajian Atas Praktek Penerjemahan Jenggotan," Jurnal Ulumuna, Vol. 15, No. 1, 2011, 108.

2 In addition to the pegon Arabic script, there are also variations of other characters in the local community in Indonesia, and the variation of this script is also used in compiling and translating pesantren books. It is like the Arabic script which is used to write Bugis-Makassar language which is then known as "Serang". Besides that, in the Wolio community on Buton island, there is also the use of this Arabic script, in the Wolio language it is called "Buri Wolio". Cho Tae Young, Aksara Serang Dan Perkembangan Tamaddun Islam di Sulawesi Selatan, (Yogyakarta: Ombak, 2012), 70.

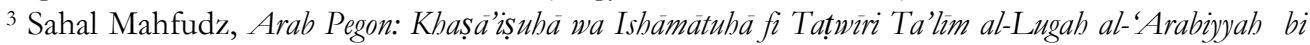
Indonesia, (Pati: Syahada Press, 2018), 26-27.

${ }^{4}$ Many experts conduct research on it, such as Herman (1968) in Israel, Greenfield (1972) in New York, Blom and Gumperz (1972) in Norwegia, Laosa (1975) in United States, Van den Berg (1985) in Taiwan, Gonzales (1985) in Phillipines, dan Shorab (1978) in New York, and many other experts of the same research domain. In Indonesia, research on the same domain is conducted by Nababan (1977), Wolff dan Poedjosoedarmo (1979), Kartomihardjo (1981), Soetomo (1985), Suwito (1987), Siregar (1987) dan Sumarsono (1993) and many other researchers. Fathur Rokhman, "Pilihan 
and maintained, as well as the purpose of language use and what messages are conveyed through a variety of languages. This also applies to the variety of Javanese used in conjugating the pesantren books. Therefore, it is important to examine the causes and reasons why a typical Javanese of pesantren is used and maintained.

Many studies have been conducted by linguists regarding conjugation, such as Irhamni's research on the Local Wisdom of Traditional Islamic Boarding Schools in Java: A Study of Jenggotan Translation Practices, and Ibn Burdah who examines the history of the model of hanging translation. However, the first study is focused more on the Javanese tradition of translation, while the second is focused on the history of the model of hanging translation. There are still many other results of research on the translation of the pesantren book, but most of the others focus on the implementation of their activities. Based on the above problems, it is important to study the model of the conjugation of books that are usually used by Kiai in some traditional Islamic boarding schools in the framework of linguistic studies. ${ }^{5}$ This study will also look at how the formulation of the Kitabi Javanese and why the variety of Javanese typically used in pesantren that continues to be preserved and maintained by the pesantren community. Further, it will also determine how the process of conjugation has become a part of the process of acculturation of Javanese and Arabic in the texts of religious books.

\section{Method}

The study used the books translated by Kiai of the northern coast of Java as its main subjects and was conducted by using the sociolinguistics approach. This approach was used by considering the relationship between the study of language and the factors applied in society. With this approach, the data can be provided, analyzed, and presented with certain methods to create new rules relevant to the research problems. ${ }^{6}$ The data were collected through observation, interview, and documentation and then were analyzed by using content analysis. This analysis method was used to see the inclination and the pattern used in the documents. The documents here referred to the translated books written by the Kiai of the northern coast of Java. These books were deliberately chosen to facilitate the study of the analysis of conjugation as well as to be able to see the variety of languages, dialects, and other linguistic phenomena.

\footnotetext{
Bahasa Sebagai Kendali Status dan Keakraban dalam Masyarakat Diglosik: Kajian Sosiolinguistik di Banyumas," Jurnal Linguistik Indonesia, Vol. 23, No. 1, 2005, 1.

${ }^{5}$ What is meant by traditional (salafiyah) does not mean old or having no change and renewal, but it means an Islamic boarding school that has long been established and has a role for hundreds of years in Indonesia. Ahmad Ubaidi Fathuddin, "Tațwìru Mawādi Ta'līmi al-Lugah al-'Arabiyyah fi alMa’āhid al-Salafiyah Min Manzūiri Ma’āyiri Muḥtawa Manhaji Ta’līmi al-Lugah al-'Arabiyah li alNāṭiqīna bi Gairihā," Alsinatuna, Vol. 1, No. 1, 2015, 30.

${ }^{6}$ Muhammad, Metode Penelitian Bahasa, (Ar-Ruzz Media, 2011), 149.
} 
Arabiyât Jurnal Pendidikan Bahasa Arab dan Kebahasaaraban, 6 (2), 2019

\section{Result and Discussion}

The Model of Pengapsahan of the Arabic Text of the Book in the Islamic Boarding School

The tradition of conjugation is a model of the translation of Arabic-language texts by putting the words or sentences under the translated vocabulary. The translation sentence is written hanging with a slope of 43 degrees. The Gandul (hanging) translation system is accompanied by a number of formulas to mark the position of words in a series of sentences, for example, the position of mubtada is symbolized with utawi (or) by using the letter "mim" ( $)$ ), khabar is symbolized with iku (that) by using the letter " $k h a$ " ( $\dot{\tau}$ ), fäil is symbolized with the word sopo/opo (who or that) and with the letter " $f a$ " (ف), maf'ul bib is symbolised with ing and with the letters "mim" and " $f a "$ " (مف). Because of the tendency of sumbolising in this analytical model, Muhammad Asif calls it as the utawi (or) translation model. ${ }^{8}$

In language studies, this conjugation tradition is unique, because this model is used to find out the meaning of the word as well as the structure of words in the text. Moreover, this model is also used to find out the interpretive meaning and syntagmatic meaning of each word. In other words, conjugating is a comprehensive language analysis model to explain the meaning of each language component contained in the text. Many terms are used to refer to the translation model of the text of this book, including the model of "gandul (hanging) meaning", "translation between lines", "hanging translation", and so forth. However, the terms seem to be limited to "translating", even though the process of translating the text of the book, is more than merely interpreting its meaning, namely explaining the in-depth meaning of the text. Therefore, this study uses the term "pengapsahan (conjugation)" which is an Arabic absorption word from the word "fashaha" with wazan (derivation) "af'ala" to "afshaha" which means "to explain the intention" (bayyana murädahu). "The word "pengapsahan (conjugation)" is a form of Javanese-Arabic convergence by adding morpheme prefix "pe-" and suffix "-an". This method is to make it easier for Javanese people to remember and utter the term. The processing model commonly used by Kiai in translating the books is by grammatical signs and symbols, as can be seen below:

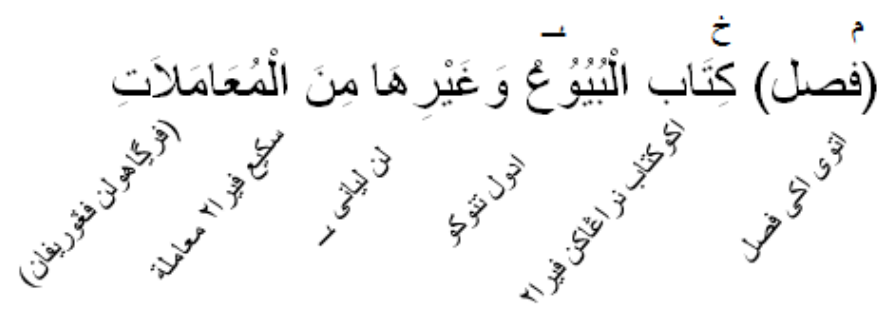

7 Islah Gusmian, "Tafsir Al-Qur'an Bahasa Jawa: Pengukuhan Identitas, Ideologi dan Politik," Jurnal Subuf, Vol. 9, No. 1, 2016, 147.

${ }^{8}$ Muhammad Asif, "Tafsir Tradisi Pesantren: Karakteristik Tafsir al-Ibriz Karya Bisri Mustofa," Jurna Subuf, Vol. 9, No. 2, 2016, 252.

9 Al-Munjid fì al-Lugah wa al-'A'Làm, (Beirut: Dār Al-Masyriq, 2008), 584; Warson Munawwir, Kamus Al-Munawwir Arab-Indonesia Terlengkap, (Surabaya: Pustaka Progressif, 1997), 1057. 
The model of conjugation above is a model of giving markings and grammatical patterns. However, in writing the translation book, the conjugation model often uses the straightforward (descriptive-interpretative) explanatory model that no longer uses linguistic signs but directly uses Javanese linguistic symbols. It is as found in the book Tiryäq al-Aghyär fi Tarjamah Burdah al-Mukbtär by KH. Bisyri Mustofa as follow:

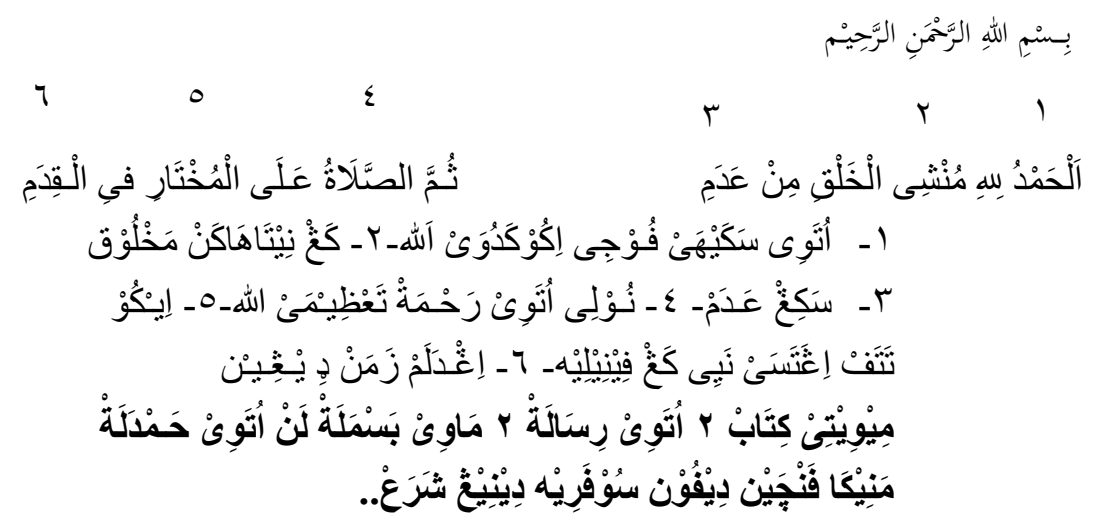

Preserving the V ariety of the Kitabi Javanese in the Pengapsaban of Islamic Boarding Schools

a. The Use of Pegon Script

As mentioned earlier, the Pegon script is a variety of characters commonly used in translating pesantren books. The pegon Arabic writing process is using the Arabic script to write Javanese. The attempt to use Arabic script is not the first time, but it has been done long before as in the writing of Malay and Bugis languages, which is known as Jawi script and Serang script. ${ }^{10}$ Both are linguistic phenomena in supporting the process of Islamisation in their respective regions.

The explanation above is supported by Cho Tae Young's research, in which he states that genealogically, the Pegon script is almost the same as the genealogy of the Jawi, Serang, and Wolio characters. The three characters above are examples of the "borrowing" process, and all refer to the Arabic script. ${ }^{11}$ Elis added that the Arabic script was used to write the current tribal languages, and the use of the Arabic script previously was adjusted to the phoneme of each language. ${ }^{12}$ The Arabic script is "borrowed" by the Javanese coastal Kiai in writing and translating pesantren books. However, there are often differences in usage among the existing books. Usually, this difference lies in the writing of Arabic letters which should be adapted to the Javanese grapheme system. For example, the word "Sira", sometimes written "Sira" and "Ira".

${ }^{10}$ One opinion says that the word "Jawi" comes from the Arabic word "al-Jawwah" to name the island of Sumatra. As Ibn Batuttah writes in his book al-Rihlah, he calls the island of Sumatra "alJawwah." The term was given by Arabs to call Sumatran people who are Muslim and speak Malay. Ellya Roza, "Aksara Arab-Melayu di Nusantara dan Sumbangsihnya dalam Pengembangan Khazanah Intektual," Jurnal Tsaqafah, Vol. 13, No. 1, 2017, 186.

${ }^{11}$ Young, Aksara Serang dan Perkembangan Tamaddun Islam di Sulawesi Selatan, 108.

${ }^{12}$ Elis Suryani, Filologi, (Bogor: Ghalia Indonesia, 2012), 127. 
Arabiyât Jurnal Pendidikan Bahasa Arab dan Kebahasaaraban, 6 (2), 2019

Uniquely, the writing differences occur in the same book with the same author, as occur in the book "Matn al-Hikm" by Kiai Shaleh Darat as follow:

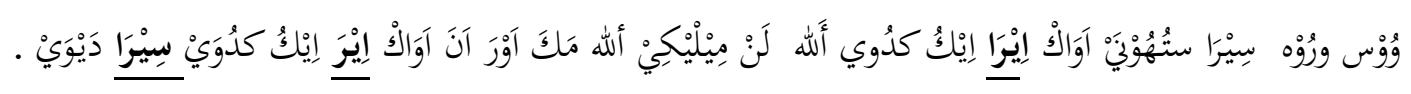

The Pegon script has several variations of grapheme according to the consonant sound system and relies on the use of i'rab symbols to express Javanese vowel sounds to write them accurately and clearly. Even though as mentioned earlier it is often inconsistent in the use of graphene pegon characters. The grapheme variations

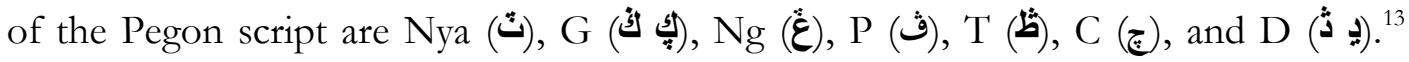
These graphemes are not found in true Arabic graphene systems. Also, in true Arabic script, there is a letter sound that is determined by the system of "harakat", as a vowel for comparison of consonant letters such as signs of Fathah, Kasrah, Dhamah, Sukun, Tasydid, and Tanwin.

\section{b. Variety Retention, Language Dialect, and the Phenomena of Diglossia}

The choice of the Javanese variety used has its characteristics and its position becomes important as a medium for writing and translating pesantren books. Sociolinguistically, the choice of language is based on the consideration of who the author is, the content of the writing, the situation of this writing and to whom the writing is intended. Therefore, the variety of Javanese in the conjugation of books can be quite varied. Furthermore, Javanese does not only function as a connecting device but also shows the symbol of the identity and level of the social status of the user. There are various social dialects such as Krama Inggil, Krama Madya, and Ngoko. Even though in general, in writing literature, there are only two stratification types of Javanese used, namely Krama and Ngoko. ${ }^{14}$

This also happened in the conjugation of pesantren books, in which Kiai uses the two Javanese varieties. The books are translated with Javanese Krama and Ngoko separately, even though the translated book is the same. It can be seen in the translation of the book "al-Unsyuty Syarh Nadhm al-Syaraf al-Umrithy fi al-Nahw" by Kiai Bisri Mustofa which is translated into the variety of Krama and Ngoko separately. It is explained by the author himself. ${ }^{15}$ However, there are other opinions which state that the language of the book is a mixture of krama and ngoko. ${ }^{16}$

In general, the Kiai uses Krama when referring to people who were of the higher rank as to the Prophet Muhammad, the companions, and also the respected scholars. As written by Kiai Shaleh Darat in his book; "... lan angendiko malih gusti Rasul Shallallahu 'alaibi wa al-sallama, Ya Bani Hasyim la ya'tinì al-Nāsu bi 'amalihim wa ta'tūnì bi

${ }^{13}$ Young, Aksara Serang dan Perkembangan Tamaddun Islam di Sulawesi Selatan, 126.

14 A. Effendi Kadarisman, Mengurai Bahasa Menyibak Budaya: Bunga Rampai Linguistik, Puitika, dan Pengajaran Bahasa, (Malang: UM Press, 2010), 136. Kudus, n.d.), 2.

15 Bisyri Mustofa, Al-Unsyuty: Syarb Nadhm al-Syaraf al-Umrithy Fi al-Nabw, (Kudus: Menara

16 Anasom, "Perkembangan Bahasa Jawa Dalam Tradisi Pesantren", (presented at the Kongres Bahasa Jawa IV Semarang, Semarang, 2006), 211. 
ansäbikum...". ${ }^{17}$ It is the same as what is written by Kiai Ahmad Abdul Hamid; “...Dawubipun kanjeng Nabi Mubammad SAW (wa al-mar'atu ra'iyatun fi baiti zaujiba wa waladibi; 'an ibn Umar). ${ }^{18}$ Many of the books are also written in the whole Javanese krama, as the book of "Taubid Jawan" by Kiai Raden Asnawi Kudus, and also the book of "Maslak al-Abid fi Tarjamah Nadhm Jauharah al-Taubid" by Kiai Ahmad Subki. ${ }^{19}$ Uniquely, the same book is translated by Kiai Shaleh Darat using the Javanese ngoko, "Tarjamah Sabili al-'Abid 'ala Jauharah al-Taubid."

Meanwhile, the variety of Ngoko Javanese is used to refer to people of the lower level. The same is the case with Javanese conversation in everyday communication. Kiai Misbah often uses the word ngoko roughly, especially for dialectics aimed at unbelievers. ${ }^{20}$ Kiai Bisri Mustofa sometimes uses Ngoko Javanese in translating his books. Technically, the choice of ngoko is for the sake of flexibility and ease of understanding, because through ngoko, the speaker and the audience eliminate psychological distance in communication. Both of them stand on the same level, so there is no need to carry out such pleasantries when using Krama Madyo or Krama Inggil. ${ }^{21}$

However, at the theoretical level, the choice of ngoko is non-playful, because, in that way, the writer must risk his authority in expressing the totality of his work. Indirectly, this method is a reflection of the responsibility for the social world of the community, so that Kiai Bisri Mustofa (writer) does not want to have more unggahungguh (politeness) and being elitist to convey his intentions. ${ }^{22}$ This Javanese model is like a coastal area which will later become a characteristic of the Javanese of the conjugation of the book.

Also, Javanese love coastal activities deliberately were chosen because of the background of their readers. In general, the translation of the pesantren's books is intended for ordinary people who want to learn about religion, most of which come from the rural community, not from the royalty. ${ }^{23}$ Therefore, the variety of ngoko is seen as appropriate in making it easier for people to understand the contents of the book. $^{24}$ This Ngoko Javanese will also vary depending on the variety of Javanese

${ }^{17}$ Muhammad Sholih Umar, "Tarjamah Sabīli Al-'Abid 'ala Jauharati al-Tauhīd” (n.d.): 23.

${ }^{18}$ Ahmad Abdul Hamid, Risälah al-Nisä’’ (Semarang: Karya Toha Putra, n.d.), 10.

${ }^{19}$ Example of krama Javanese in the book; (Tanbih): artosipun sobabab puniko tiang ing kang menangi yuswonipun Kangjeng Nabi Muhammad SAW wonten bumi saksampunipun dados Nabi, sarana iman senaoso mboten sumerep lan dereng baligh. Lan ing kang name tabi'in, inggih puniko tiang ing kang sampun nati kempal sareng kalian sohabah. Wallahu 'alam. Ahmad Subki, Maslaku al-'ábid Fi Tarjamati Nadhmi Jaubarati al-Taubid, (Semarang: Karya Toha Putra, n.d.), 52.

${ }^{20}$ Supriyanto, "Kajian Al-Qur’ān dalam Tradisi Pesantren: Telaah Atas Tafsir al-Iklīl Fi Ma’āni al-Tanzil," Jurnal Tsaqafah, Vol. 12, No. 2, 2016, 293.

${ }^{21}$ Maslukhin, "Kosmologi Budaya Jawa dalam Tafsir Al-Ibrīz Karya KH. Bisri Mustofa," Mutawatir: Jurnal Keilmuan Tafsir Hadis, Vol. 5, No. 1, 2015, 82.

${ }^{22}$ Maslukhin, "Kosmologi Budaya Jawa Dalam Tafsir Al-Ibrīz Karya KH. Bisri Mustofa," 82.

${ }^{23}$ Bisyri Mustofa, Tanwiru al-Duja fi fi Tarjamati Safinati al-Najā, (Semarang: Karya Toha Putra, n.d.), 2; Bisyri Mustofa, Tiryāqu al-Aghyār fi Tarjamati Burdati al-Mukbtār, (Kudus: Menara Kudus, n.d.).

${ }^{24}$ Muhammad Sholih Umar, Majmü'ab al-Syarīah al-Käfiyah li al-Awäm, (Semarang: Karya Toha Putra, n.d.), 278; Muhammad Sholih Umar, Matn al-Hikam (Semarang: Karya Toha Putra, n.d.), 2; 
dialects used by the community in one particular area. And this has become a linguistic phenomenon in its own right, namely the emergence of coastal Javanese dialects as the media of conjugation of the books, and the dialect is almost rarely used in everyday conversation, ${ }^{25}$ not like the colloquial speech of Javanese people. ${ }^{26}$

The preservation of Kitabi Javanese is also based on the consideration of the phenomenon of diglossia. In bilingual and multilingual societies, it usually results in the use of two or more languages that are "diglossic", i.e. there are choices of language usage that are good, following different social contexts and functions. In the context of multilingual society, the speech is not limited to a variety of codes in its "repertoire" or limited to a monotonous and unchanging language which does not show respect, ${ }^{27}$ antics, and the distance of social roles through the transfer of a variety of codes to other types. ${ }^{28}$ This phenomenon of diglossia also occurred in Javanese society, including the Kiai as writers and translators of the book. At least diglossia, as in Ferguson's view, introduces the possibility of diglossia in a language.

The phenomenon of diglossia occurs because of the diversity of dialects in Javanese. As explained earlier that the variety of book dialects is a variety of dialects that are rarely used in everyday conversation. Elen Indrasari and Dwi Kurniasih identify forms of bilingualism in the "yellow" book by looking at Javanese words that are rarely used. ${ }^{29}$ Word grouping is based on four categories, namely; pronoun, verb, adjective, and noun. What Elen had determined that the author adds other words found in the Javanese variety of coastal dialects. The author also adds a column to the description of the coastal Kiai book where the typical words of the book are found.

Table 1 : Javanese and Indonesian pronouns

\begin{tabular}{|c|c|c|cc|}
\hline No & Javanese & Indonesian & \multicolumn{2}{|c|}{ Book Code: Page } \\
\hline 1 & Sira & Anda & $\mathbf{( 2 : 3 0 ) , \quad ( 4 : 2 1 ) , \quad ( 9 : 5 ) ,}$ \\
\hline
\end{tabular}

Muslih bin Abdurrahman al- Qandaly, Al-Nūr al-Burhān, (Semarang: Karya Toha Putra, n.d.), 9; Bisyri Mustofa, Al-Azwād al-Mushthafawiyyah fi Tarjamati al-Araba'in al-Nawawiyyah, (Kudus: Menara Kudus, 1375), 4.

25 Theoretically, the main types of languages in a complex language society can be categorized as follows (1) literary standards, which are used in the most official and written discourses; (2) the standard of respectable language conversation; (3) regional standards; (4) sub-standard, which is clearly different from (1), (2), and (3), and is used to speak in European countries by the lower middle class; (5) local dialects. For a detailed example, Muhammad Afifuddin, Madkhal Ila Ilm al-Lughah al-Ijtimä'iy, (Malang: Lisan 'Arabiy, 2016), 24-25; Bloomfield, Language, (Foreign Language Teaching and Research Press, t.t.), 52 .

${ }^{26}$ Qallaqial speech is the utterance used in daily communication. Isti Mureni, Glosarium Linguistik, (Jakarta: Yayasan Obor Indonesia, 2002), 16.

${ }^{27}$ Repertoire is all language and its varieties owned or mastered by the speaker. Abdul Chaer and Agustina Leonie, Sosiolinguistik: Perkenalan Awal, (Jakarta: Rineka Cipta, 2014), 35.

${ }^{28}$ Moch Ali, "Bahasa Jawa Kitabi Dialek Madura Dalam Naskah :Careta Qiyamat," Litera, Vol. 6, No. 1, 2007, 24.

29 Elen Indrasari Indasari and Dwi Kurniasih, "Kedwibahasaan Sebagai Upaya Pemahaman dalam Pembelajaran Kitab Kuning di Pondok Pesantren Mahasiswa Darussalam," Transformatika: Jurnal Bahasa, Sastra dan Pengajarannya, Vol. 2, No. 1, 2018, 42-44. 
Arabiyât Jurnal Pendidikan Bahasa Arab dan Kebahasaaraban, 6 (2), 2019

\begin{tabular}{|c|c|c|c|}
\hline & & & (10:4), (11:5), \\
\hline 2 & Ingsun & $\mathrm{Aku}$ & $\begin{array}{l}\text { (5:17), (7:4), (10:9), } \\
(11: 4),(13: 65),(18: 29),\end{array}$ \\
\hline 3 & Kawulo/ Kulo & Saya & $\begin{array}{l}(3: 2),(4: 20), \quad(11: 57), \\
(12: 5),(13: 65),\end{array}$ \\
\hline 4 & Kito & Kita & $\begin{array}{l}(3: 2), \quad(12: 27), \quad(11: 47), \\
(17: 4)\end{array}$ \\
\hline
\end{tabular}

Table 2: Javanese and Indonesian Verbs

\begin{tabular}{|c|c|c|l|}
\hline No & Javanese & Indonesian & \multicolumn{1}{|c|}{ Book Code: Page } \\
\hline 1 & Mertelaaken & Menjelaskan & $(5: 25) .(6: 8),(11: 11)$ \\
\hline 2 & Nuli-nuli & Terus-menerus & $(1: 19)$ \\
\hline 3 & Ngerkso & Menjaga & $(4: 21),(13: 73),(16: 49)$ \\
\hline 4 & Nganggit & Merasa/ menulis & $(7: 4),(8: 21),(18: 28)$ \\
\hline 5 & Ndinginake & Mendahulukan & $(4: 20)$ \\
\hline 6 & Kaperdi/Merdi & Terbebani & $(11: 5),(18: 31),(19: 7)$ \\
\hline 7 & Ngudaneni & Mengetahui & $(12: 27),(13: 43)$, \\
\hline 8 & Mengo & Berpaling & $(12: 60)$ \\
\hline 9 & Nyumbadani & Menjawab/mengabulkan & $(13: 65)$ \\
\hline 10 & Deleng & Melihat & $(19: 8)$ \\
\hline
\end{tabular}

Table 3: Javanese and Indonesian Adjectives

\begin{tabular}{|c|c|c|l|}
\hline No & Javanese & Indonesian & \multicolumn{1}{|c|}{ Book Code: Page } \\
\hline 1 & Gandrung & Terbuai & $(10: 5)$, \\
\hline 2 & Wangkot & Keras Kepala & $(19: 2)$ \\
\hline 3 & Apes & Lemah & $(11: 50),(18: 35)$ \\
\hline 4 & Bendu & Marah & $(9: 7)$ \\
\hline 5 & Gorohi & Bohong & $(7: 17)$ \\
\hline 6 & Lacut & Nakal & $\mathbf{( 1 3 : 7 6 )}$ \\
\hline 7 & Depe-depe & Rendah hati & $\mathbf{( 1 9 : 3 )}$ \\
\hline
\end{tabular}


Ara6iyât Jurnal Pendidikan Bahasa Arab dan Kebahasaaraban, 6 (2), 2019

Table 4: Javanese and Indonesian Nouns

\begin{tabular}{|c|c|c|l|}
\hline No & Javanese & Indonesian & \multicolumn{1}{|c|}{ Book Code: Page } \\
\hline 1 & Cumleret & Kilatan & $(10: 2)$ \\
\hline 2 & Pituduh & Petunjuk & $(9: 5)$ \\
\hline 3 & Kemiren & Mata kaki & $(1: 11)$ \\
\hline 4 & Sewiji-wïi & Satu-satu & $(4: 22),(12: 27),(15: 17)$ \\
\hline 5 & Rubo & Keselamatan & $\mathbf{( 7 : 5 ) , ( 1 1 : 2 ) , ( 1 2 : 4 )}$ \\
\hline
\end{tabular}

Table 5: Javanese and Indonesian Prepositions

\begin{tabular}{|c|c|c|l|}
\hline No & Javanese & Indonesian & \multicolumn{1}{|c|}{ Book Code: Page } \\
\hline 1 & Utawi & Adalah, Selain & $(1: 10),(3: 2),(7: 14)$ \\
\hline 2 & Kelawan & Dengan & $(7: 10),(13: 65)$ \\
\hline 3 & Kang & Yang & $(7: 10)$ \\
\hline 4 & Yento & Jika & $(1: 8),(12: 26),(11: 48)$ \\
\hline 5 & Ing ndalem & Di dalam & $(4: 21),(7: 25),(8: 47),(10: 3)$ \\
\hline 6 & Iki-iku & Ini-itu & $(14: 2),(17: 25)$ \\
\hline 7 & Tumeka & Sampai & $(10: 10),(11: 54)$ \\
\hline 8 & Nalikane & Jikalau & $(13: 65)$ \\
\hline 9 & Saking/sangking & Dari & $(15: 45),(16: 57)$ \\
\hline 10 & Keduwe & Bagi/milik & $(15: 30)$ \\
\hline 11 & Den & Di... & $(11: 57),(14: 20)$ \\
\hline 12 & Ing Atase & Di atas/ kepada & $(15: 64)$ \\
\hline 13 & Maring/marang & Kepada & $(15: 59)$ \\
\hline
\end{tabular}

Actually there are many other words that can be categorized in various regional dialects as well as social dialects. The numbering on the code page was intentionally used to show the names of the Javanese pesantren books by coastal Kiai where the Javanese words of the book were found. ${ }^{30}$

${ }^{30}$ Code numbering and labeling are as follow Mustofa, Tanwiru al-Dujā fi Tarjamati Safinati alNajā; Qandaly, Al-Nür al-Burbān.; Ahmad Subki, Nailul Munā: Tarjamah al-Du'à bi al-Asmä' al-Husnā, (Pekalongan: Ma'had al-Ulūm al-Syar'iyyah "al-Masyhad, n.d.); Umar, Majmü'ah al-Syarìah al-Käfiyah li alAwàm; Bisyri Mustofa, An-Nibrasiyyah Syrah al-Jurumiyyah, (Kudus: Menara Kudus, n.d.); Ahmad Subki, Al-Targib wa al-Tabdzib: Matn al-Ghayah wa al-Taqrï, (Semarang: al-Muna, n.d.); Bisyri Mustofa, Rawīhatu al-Aqwäm: Kangge Ngertosi Isi Nadham Aqidah al-'Awām, (Rembang, n.d.); Ahmad Abdul Hamid, Risälatu al-Siyam, (Semarang: Karya Putra, 1956); Mustofa, Tiryäqu al-Aghyär fi Tarjamati Burdati al-Mukbtär, Subki, 
Acculturation of Arabic-Javanese in the Tradition of the Analysis of Ngapsabi (Conjugating) in Islamic Boarding Schools

The process of language acculturation in the conjugation tradition occurs in the phenomenon of Kitabi Javanese languages used in the writing or translation of books in Islamic boarding schools. There are at least three elements contained in the book writing model with the variety of Kitabi Javanese languages, namely; the pegon Arabic script, coastal Javanese dialect, and fusha Arabic. The pegon script is a process of acculturation of language as a manifestation of the acculturation of Islamic and Javanese cultures. ${ }^{31}$ A usage, diaspora, the development of pegon Arabic cannot be separated from the role of groups of Javanese people who are strongly influenced by Islamic culture originating from Arab countries. Because of the difficulty of translating words in Islamic and Arabic concepts specifically into Javanese, there should be attempts to adopt original Javanese sounds/phonemes written in the Pegon script. ${ }^{32}$

The process of acculturation of Arabic-Javanese or vice versa also occurs in the reference of lexicons referring to the Javanese of the coastal dialect, while the grammar refers to the fush $\bar{a}$ Arabic grammar. The emergence of the Kitabi Javanese as a customized Javanese grammar that is fully adapted from the fushā Arabic requires syncretization of language that is enculturated between Arabic which acts as the source language and Javanese which acts as the target language due to the process of Islamisation. ${ }^{33}$ Most of the Islamic boarding schools in the coastal areas of Central Java are written in Kitabi Javanese. The following is the example taken from Majmüatu al-Syarìah al-Käfiyah li al-'Awām.

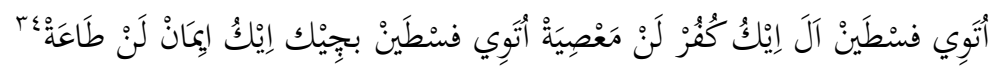

The text above is one of the models of Kitabi Javanese, where the characters used are Arabic, the language used is Javanese, and the grammatical structure in fusha

Maslaku Al-äbid Fi Tarjamati Nadbmi Jaubarati al-Taubid; Misbah Zainal Mustofa, Al-Iklìl Fi Ma'āni al-

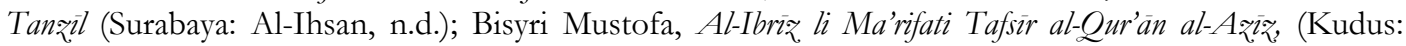
Menara Kudus, n.d.); Misbah Zainal Mustofa, Tarjamah Matn Al-Jurümiyyah Fi Qawā'idi al-'Arabiyyah bi Ta'Liqäti Bangilāniyyah, n.d.; Misbah Zainal Mustofa, Tarjamah Qiṣah Al-Mi'raj, (Pekalongan: Hasan Idrus al-Athas, n.d.); Misbah Zainal Mustofa, Tarjamah Maulid al-Barzanji, (Bojonegoro: Maktabah al-Balagh, n.d.); Bisyri Mustofa, Nadham Al-Sulam al-Muwaraq fi al-Manthiq, (Kudus: Menara Kudus, n.d.); Umar, “Tarjamah Sabīli al-'Abid 'ala Jauharati al-Tauhīd”; Bisyri Mustofa, Kitab Syi'ir Ngudi Susilo, (Kudus: Menara Kudus, n.d.).

31 Acculturation is a form of enculturation (the process of learning and internalizing culture and the values adopted by indigenous people). Acculturation can also be defined as a form of cultural change that is reinforced by cultural groups emphasizing the acceptance of new patterns and culture and the characteristics of indigenous communities by minority groups Dedi Mulyana, Komunikasi Antarbudaya, (Bandung: Remaja Rosdakarya, 2001), 159.

32 Naufan Noordyanto, "Tipografi Arab Pegon dalam Praktik Berbahasa Madura di Tengah Dinamika Kebudayaan yang Diusung Huruf Latin," Jurnal Dekave, Vol. 9, No. 2, 2016, 33.

${ }^{33}$ Moch Ali, "Urgenitas Bahasa Jawa Kitabi sebagai Identity Marjer Kitab-kitab Turats al-'Araby di Pesantren Jawa Timur," in Artikel Bunga Rampai Buku, (Surabaya: Airlangga University Press, 2012), 6.

${ }^{34}$ Umar, Majmü'ah al-Syarìah Ak-Käfiyah li al-Awäm, 5. 
Ara6iyât Jurnal Pendidikan Bahasa Arab dan Kebahasaaraban, 6 (2), 2019

Arabic. The Kitabi Javanese system is found in many other books of scholars, especially books written in the $19^{\text {th }}$ to $20^{\text {th }}$ centuries, such as the translation books of Kiai Ahmad Rifa'i, Kiai Bisri Musthofa, Kiai Misbah, Kiai Raden Asnawi, Kiai Ahmad Abdul Hamid, Kiai Muslih, Kiai Ahmad Mutohar, Kiai Yahya Arief, Kiai Akhmad Syakowi Amin, Kiai Subki Masyhadi, and many other translated books written by Kiai in coastal areas.

\section{(Elements of Kitabi Javanese)}

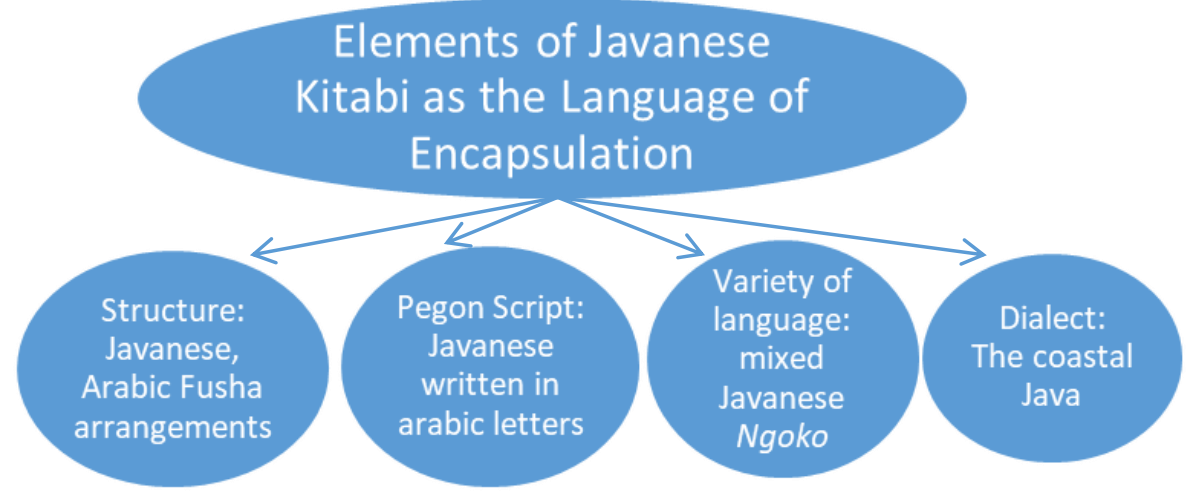

The acculturation process can also be seen on the Javanese word derived from Arabic. Therefore, to establish the Kitabi Javanese as an academic language used in Islamic boarding school, the scholars attempted to absorb some Arabic words into Javanese. Besides, in ngapsahi (conjugating) the books, the scholars also translated the meaning of role elements which is usually in the form of qarinah-qarinah. For example, qarinah al-taubid wa al-taukid on maf'ul mutlaq, wich is usually translated as "kelawan" (with) and "temenan" (indeed) in sentences such as "wakallama/ lan ndawub/ sinten/ Allab/ Musa/ ing Nabi Musa/ taklimal klawan/ ndawub temenan, (Allah has indeed tols Musa). The Qarinah al-Mulabasab for syntactical function hal is translated as "hale", like in sentence "al-sâbi'/ utawi kang kaping pitu/ iku/ al-I'tidâlu/ 'itidal/ bi an yantsibal klawan yențo jejek/ qâiman/ bale ngadek.."

In historical records, the influence of the style of the local language as a process of acculturation with Arabic occurs not only in Javanese literary books but also in literary writing in the Malay language. This influence usually lies in the vocabulary and syntactic levels as in Javanese. In Malay literature, writing styles are often found such as; " ...maka sekarang dengar oleh kamu daripada segala raja-raja yang kafir dan adil betapa ia mengerjakan pekerjaan kerajaan dan betapa ia memeliharakan rakyat dan betapa ia menjadikan makmur dari segala negeri dan betapa ia berbuat adil dan insyaf dan betapa ia akan kebajikan kerajaan itu". The uses of "dan" (and) and "daripada" (of) is influenced by Arabic the words of "و" (dan), " من (daripada). Even in old literature, words of ini hari (today), ini malam (this night), ini pagi (this morning),

${ }^{35}$ Bisyri Mustofa, Safinah Al-S \}alăh Khanti Bahasa Jawa (Kudus: Menara Kudus, 1975), 46. 
and so on are often found, which actually comes from the words هذا , هذا الليل ,هذا اليوم الصبح. It is literally translated word by word. ${ }^{36}$

Besides, the process of acculturation of Javanese in the language of the book also occurred due to the phenomenon of diglossia as an implication of multilingual society, which eventually led to the tendency of the language "code-switching" or "code-mixing." Code-switching is the use of two languages or variations of language alternately in the same discourse. The bilingual speaker switches from one language system to another. On the other hand, code-mixing is the retrieval of elements from other languages into another language being used because there are no correct elements in the language used. ${ }^{37}$

This code-mixing phenomenon is very much found in the translation books of coastal Kiai. This is understandable considering that the Kiai themselves are part of the diglossic community, which understands many languages and the various existing dialects. The example of code-mixing found in the book "Fadbl al-Mu'thi; Tarjamah Nadhm al-Syaraf al-Umrithy", 38 as follow:

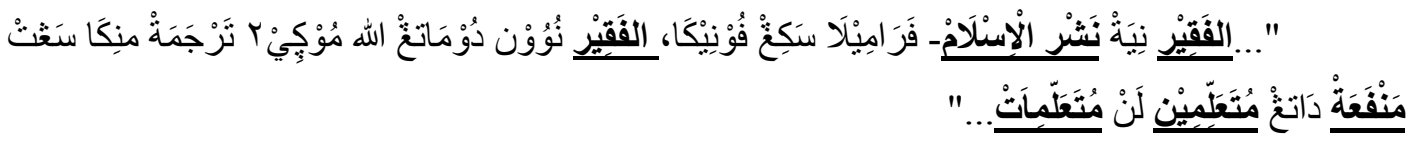

Code mixing of Javanese-Arabic can also be found in the book Matn al-Hikam:

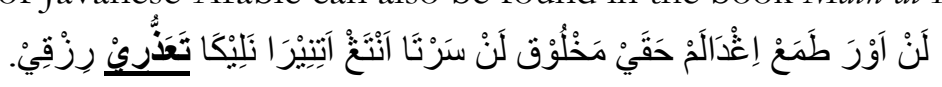

And there are still many more phenomena to intervene in the books of other Kiai of Islamic boarding schools. Code mixing also occurs in the krama-ngoko Javanese variety. This phenomenon can be seen in the translation of KH. Misbah Musthafa on surah al-Baqarah verses 30-31: "Qäla Innï 'alamu mà la ta'lamün/Dawub sopo Allah setubune ingsun iku ngudadeni ingsun ing perkoro kang ora weruh sira kabeh ing ma". "Wa 'allamma Adam al-as,mā Kullahā... / Lan paring pirso sopo Allah ing Nabi Adam ing pirapira asma". "The words ngudadeni, weruh and pirso have the same meaning, but the variety is different. Those are a few examples of code-mixing models as forms of acculturation in Javanese-Arabic that occur in the process of translation (conjugation) of pesantren books written and/or translated by the Kiai of coastal Java.

${ }^{36}$ Bakar Hatta, Sastra Nusantara,: Suatu Pengantar Studi Sastra Melayu, (Jakarta: Balai Aksara, 1984), $50-51$.

37 Edi Jatmiko, "Tembung Lan Gambare Kamus Visual Ragam Diksi Bahasa Jawa Tingkat Ngoko," Jurnal Dekave, Vol. 7, No. 2, 2014, 37; Made Iwan Indrawan Jendra, Sociolinguistics; The Study of Societies' Languages, (Yogyakarta: Graha Ilmu, 2012), 73.

38 Ahmad Subki, Fadbl Al-Mu'ti: Tarjamah Nadhm al-Syaraf al-Umrity fi Ilm al-Nabw ala al-Thariqah al-Rembāniyyah, (Pekalongan: Al-Masyhad, n.d.), 1.

39 Mustofa, Al-Iklìl fi Ma'ani al-Tanæịl, 27-28. 
Ara6iyât Jurnal Pendidikan Bahasa Arab dan Kebahasaaraban, 6 (2), 2019

\section{Conclusion}

From the above discussion, it can be concluded that: First, the conjugation model is a special model for Arabic texts created by pesantren scholars. Broadly speaking, some of the elements in the process are; (1) syntactic symbols which usually indicate slot paths or syntactic functions; (2) a set of signs and symbols of riju and marja'; (3) giving barakat as a sign of position Trab that can explain not only in the dimensions of the class (syntactic categories) in Arabic texts but also cohesive relationships of each word in the text; (4) the use of local language used in translation, both the translation of every word meaning (lexical meaning), as well as the translation of the dimensions of text structure elements (grammatical analysis); (5) interpretation of the meaning of the text carried out for additional explanations. The Pengapsahan model is very helpful for students in understanding for Arabic books. Second: The variety of languages used in the conjugation of the book is the variety of coastal Javanese dialects and has become a language corpus of its own called Kitabi Javanese. The elements Kitabi Javanese consist of; (1) the use of the Pegon Arabic script as the literary medium; (2) the use of ngoko of the coastal Javanese dialect, although sometimes there is also the Krama Javanese used (as a variety of social dialects). This dialect difference is due to the phenomenon of the diglossia among the Kiai in the Islamic boarding schools, and with the phenomenon of diglossia it also causes the use of code-mixing in the translation of pesantren books; (3) the use of fusha Arabic structures in the translation process. The continuous use of Kitabi Javanese in the Islamic boarding school also serves as a way to introduce as well as to preserve this Javanese culture as one of the local languages in Indonesia.

Third: The process of acculturation of Arabic-Javanese in the conjugation tradition of pesantren books is a consequence of the acculturation of Islamic and Javanese cultures along with the Islamisation movement in the archipelago. The forms of acculturation of Arabic-Javanese in the conjugation tradition of pesantren books are; the emergence of new pesantren characters, which are often referred to as the pegon characters; the number of Javanese translation books made in the fusha Arabic structure. The two elements (the pegon script) and writing structure systems merged into a new Javanese language identity, namely Kitabi Javanese. Another form of Javanese-Arabic acculturation is the existence of code-mixing phenomenon in the writing and translation books in Islamic boarding schools, both Javanese-Arabic codes, Indonesian-Javanese, and code mixing of Javanese Krama-Ngoko. The JavaneseArabic acculturation phenomenon can be a new Javanese language corpus Commonly used in Islamic boarding schools, which can sociolinguistics study.[

\section{REFERENCES}

Afifuddin, Muhammad. Madkhal ila Ilm al-Lughah al-Ijtimä'iy. Malang: Lisan 'Arabiy, 2016.

Ali, Moch. "Bahasa Jawa Kitabi Dialek Madura dalam Naskah: Careta Qiyamat." Litera, Vol. 6, No. 1, 2007. 
Arabiyât Jurnal Pendidikan Bahasa Arab dan Kebahasaaraban, 6 (2), 2019

Ali, Moch. "Urgenitas Bahasa Jawa Kitabi Sebagai Identity Marjer Kitab-Kitab Turats al-'Araby Di Pesantren Jawa Timur.” In Artikel Bunga Rampai Buku. . Surabaya: Airlangga University Press, 2012.

Anasom. "Perkembangan Bahasa Jawa dalam Tradisi Pesantren." Semarang, 2006.

Asif, Muhammad. "Tafsir Tradisi Pesantren: Karakteristik Tafsir al-Ibriz Karya Bisri Mustofa." Jurna Subuf, Vol. 9, No. 2, 2016.

Bloomfield. Language. Foreign Language Teaching and Research press, n.d.

Chaer, Abdul, and Agustina Leonie. Sosiolinguistik: Perkenalan Awal. Jakarta: Rineka Cipta, 2014.

Fathuddin, Ahmad Ubaidi. "Tațwīru Mawādi Ta'līmi al-Lugah al-'Arabiyyah fi alMa'āhid al-Salafiyah min Manẓūri Ma’āyiri Muḥtawa Manhaji Ta'līmi al-Lugah al-'Arabiyah li al-Nāṭiqīna bi Gairihā.” Alsinatuna, Vol. 1, No. 1, 2015.

Gusmian, Islah. "Tafsir Al-Qur'an Bahasa Jawa: Pengukuhan Identitas, Ideologi dan Politik." Jurnal Suhuf, Vol. 9, No. 1, 2016.

Hamid, Ahmad Abdul. Risālah al-Nisā'. Semarang: Karya Toha Putra, n.d.

Hamid, Ahmad Abdul. Risālatu al-Șiyām. Semarang: Karya Putra, 1956.

Hatta, Bakar. Sastra Nusantara,: Suatu Pengantar Studi Sastra Melayu. Jakarta: Balai Aksara, 1984.

Indasari, Elen Indrasari, and Dwi Kurniasih. "Kedwibahasaan Sebagai Upaya Pemahaman dalam Pembelajaran Kitab Kuning di Pondok Pesantren Mahasiswa Darussalam." Transformatika: Jurnal Bahasa, Sastra dan Pengajarannya, Vol. 2, No. 1, 2018.

Irhamni. "Kearifan Lokal Pendidikan Pesantren Tradisional Di Jawa: Kajian Atas Praktek Penerjemahan Jenggotan.” Jurnal Ulumuna, Vol. 15, No. 1, 2011.

Jatmiko, Edi. "Tembung Lan Gambare Kamus Visual Ragam Diksi Bahasa Jawa Tingkat Ngoko." Jurnal Dekave, Vol. 7, No. 2, 2014.

Jendra, Made Iwan Indrawan. Sociolinguistics; The Study of Societies' Languages. Yogyakarta: Graha Ilmu, 2012.

Kadarisman, A. Effendi. Mengurai Bahasa Menyibak Budaya: Bunga Rampai Linguistik, Puitika, Dan Pengajaran Bahasa. Malang: UM Press, 2010.

Ma'luf, Louis. Al-Munjid fì al-Lugah wa al-'A'lām. Beirut: Dār Al-Masyriq, 2008.

Mahfudz, Sahal. Arab Pegon: Khașāiṣuhā wa Ishāmātuhā fi Tațìri Ta'lìm al-Lugah al'Arabiyyah bi Indonesia. Pati: Syahada Press, 2018.

Maslukhin. "Kosmologi Budaya Jawa Dalam Tafsir Al-Ibrīz Karya KH. Bisri Mustofa." Mutawatir: Jurnal Keilmuan Tafsir Hadis, Vol. 5, No. 1, 2015.

Muhammad. Metode Penelitian Bahasa. Ar-Ruzz Media, 2011.

Mulyana, Dedi. Komunikasi Antarbudaya. Bandung: Remaja Rosdakarya, 2001. 
Arabiyât Jurnal Pendidikan Bahasa Arab dan Kebahasaaraban, 6 (2), 2019

Munawwir, Warson. Kamus Al-Munawwir Arab-Indonesia Terlengkap. Surabaya: Pustaka Progressif, 1997.

Mureni, Isti. Glosarium Linguistik. Jakarta: Yayasan Obor Indonesia, 2002.

Mustofa, Bisyri. Al-Azwād al-Mushthafawiyyah fi Tarjamati al-Araba'in al-Nawawiyyah. Kudus: Menara Kudus, 1375.

Mustofa, Bisyri. Al-Ibriz li Ma'rifati Tafsìr al-Qur'än al-Ažiz. Kudus: Menara Kudus, n.d.

Mustofa, Bisyri. Al-Unsyuty: Syarh Nadhm al-Syaraf al-Umrithy fi al-Nabw. Kudus: Menara Kudus, n.d.

Mustofa, Bisyri. An-Nibrasiyyah Syrah al-Jurumiyyah. Kudus: Menara Kudus, n.d.

Mustofa, Bisyri. Kitab Syi'ir Ngudi Susilo. Kudus: Menara Kudus, n.d.

Mustofa, Bisyri. Nadham Al-Sulam al-Muwaraq Fi al-Manthiq. Kudus: Menara Kudus, n.d.

Mustofa, Bisyri. Rawīhatu Al-Aqwām: Kangge Ngertosi Isi Nadham Aqidah al-'awàm. Rembang, n.d.

Mustofa, Bisyri. Safinah al-Salāh Khanti Bahasa Jawa. Kudus: Menara Kudus, 1975.

Mustofa, Bisyri. Tanwìru al-Dujā fi Tarjamati Safinati al-Najā. Semarang: Karya Toha Putra, n.d.

Mustofa, Bisyri. Tiryāqu al-Aghyār fi Tarjamati Burdati al-Mukhtār. Kudus: Menara Kudus, n.d.

Mustofa, Misbah Zainal. Al-Iklīl fi Ma'āni al-Tanæịl. Surabaya: Al-Ihsan, n.d.

Mustofa, Misbah Zainal. Tarjamah Matn Al-Jurümiyyah fi Qawä'idi al-'Arabiyyah bi Ta'liqāti Bangilāniyyah, n.d.

Mustofa, Misbah Zainal. Tarjamah Maulid al-Barzanji. Bojonegoro: Maktabah al-Balagh, n.d.

Mustofa, Misbah Zainal. Tarjamah Qiṣah al-Mi'raj. Pekalongan: Hasan Idrus al-Athas, n.d.

Noordyanto, Naufan. "Tipografi Arab Pegon Dalam Praktik Berbahasa Madura Di Tengah Dinamika Kebudayaan Yang Diusung Huruf Latin.” Jurnal Dekave, Vol. 9, No. 2, 2016.

al-Qandaly, Muslih Bin Abdurrahman. Al-Nūr al-Burhān. Semarang: Karya Toha Putra, n.d.

Rokhman, Fathur. "Pilihan Bahasa Sebagai Kendali Status dan Keakraban dalam Masyarakat Diglosik: Kajian Sosiolinguistik di Banyumas.” Jurnal Linguistik Indonesia, Vol. 23, No. 1, 2005.

Roza, Ellya. "Aksara Arab-Melayu di Nusantara dan Sumbangsihnya dalam Pengembangan Khazanah Intektual.” Jurnal Tsaqafah, Vol. 13, No. 1, 2017.

Subki, Ahmad. Al-Targīb wa al-Tabdzīb: Matn al-Ghāyah wa al-Taqrīb. Semarang: alMuna, n.d. 
Ara6iyât Jurnal Pendidikan Bahasa Arab dan Kebahasaaraban, 6 (2), 2019

Subki, Ahmad. Fadhl al-Mu'ti: Tarjamah Nadhm al-Syaraf al-Umrity fi Tlm al-Nahw ala alThariqah al-Rembāniyyah. Pekalongan: al-Masyhad, n.d.

Subki, Ahmad. Maslaku al-'ábid fi Tarjamati Nadbmi Jaubarati al-Taubid. Semarang: Karya Toha Putra, n.d.

Subki, Ahmad. Nailul Munā: Tarjamah al-Du'à bi al-Asmā' al-Husnā. Pekalongan: Ma'had al-Ulūm al-Syar'iyyah "al-Masyhad, n.d.

Supriyanto. "Kajian Al-Qur'ān dalam Tradisi Pesantren: Telaah Atas Tafsir al-Iklīl fi Ma’āni al-Tanzîl.” Jurnal Tsaqafah, Vol. 12, No. 2, 2016.

Suryani, Elis. Filologi. Bogor: Ghalia Indonesia, 2012.

Umar, Muhammad Sholih. Majmū'ah al-Syarìah al-Käfiyah li al-Awām. Semarang: Karya Toha Putra, n.d.

Umar, Muhammad Sholih. Matn al-Hikam. Semarang: Karya Toha Putra, n.d.

Umar, Muhammad Sholih. “Tarjamah Sabīli Al-'Abid 'ala Jauharati al-Tauhīd” (n.d.).

Young, Cho Tae. Aksara Serang dan Perkembangan Tamaddun Islam di Sulawesi Selatan. Yogyakarta: Ombak, 2012. 